Communication

\title{
Unprecedented Hexanuclear Cobalt(II) Nonsymmetrical Salamo-Based Coordination Compound: Synthesis, Crystal Structure, and Photophysical Properties
}

\author{
Zong-Li Ren, Fei Wang, Ling-Zhi Liu, Bo-Xian Jin and Wen-Kui Dong * \\ School of Chemical and Biological Engineering, Lanzhou Jiaotong University, Lanzhou 730070, China; \\ 18894490797@163.com (Z.-L.R.); wangfei3986@163.com (F.W.); 1lz1009663202@126.com (L.-Z.L.); \\ jinboxiao000@163.com (B.-X.J.) \\ * Correspondence: dongwk@126.com
}

Received: 26 February 2018; Accepted: 20 March 2018; Published: 22 March 2018

\begin{abstract}
A novel hexanuclear $\mathrm{Co}$ (II) coordination compound with a nonsymmetrical Salamo-type bisoxime ligand $\mathrm{H}_{4} \mathrm{~L}$, namely $\left[\left\{\mathrm{Co}_{3}(\mathrm{HL})(\mathrm{MeO})(\mathrm{MeOH})_{2}(\mathrm{OAc})_{2}\right\}_{2}\right] \cdot 2 \mathrm{MeOH}$, was prepared and characterized by elemental analyses, UV-vis, IR and fluorescence spectra, and X-ray single-crystal diffraction analysis. Each $\mathrm{Co}(\mathrm{II})$ is hexacoordinated, and possesses a distorted $\mathrm{CoO}_{6}$ or $\mathrm{CoO}_{4} \mathrm{~N}_{2}$ octahedrons. The $\mathrm{Co}$ (II) coordination compound possesses a self-assembled infinite 2D supramolecular structure with the help of the intermolecular $\mathrm{C}-\mathrm{H} \cdots \mathrm{O}$ interactions. Meanwhile, the photophysical properties of the Co(II) coordination compound were studied.
\end{abstract}

Keywords: nonsymmetrical Salamo-type ligand; Co(II) coordination compound; crystal structure; synthesis; photophysical property

\section{Introduction}

Salen ( $N, N^{\prime}$-Disalicylideneethylenediamine) and its derivatives play an important role in inorganic chemistry [1-10], which are gained via the condensation reaction of diamines with salicylaldehyde or its analogues, and can coordinate to transition metal ions in a tetradentate chelating mode to form a neutral metal coordination compound [11-18]. Such coordination compounds have been extensively investigated as nonlinear optical materials [19], catalysts [20,21], strong activities with DNA, and so on [22-29]. In addition, some of these coordination compounds possess interesting magnetic properties [30-32]. Meanwhile, supramolecular chemistry has recognized Salen-type coordination compounds because of intermolecular hydrogen bonding interactions, $\mathrm{C}-\mathrm{H} \cdots \pi$ and $\pi \cdots \pi$ stacking interactions consist in chelate rings and the associated aromatic rings [33-42]. In recent years, our focus switched to the syntheses, structures, and properties of metal coordination compounds with Salamo (2,2'-[Ethylenedioxybis(nitrilomethyli-dyne)]diphenol) and its various derivatives derived from its constitutional units with different substituent groups [43-49]. The structural motifs of these coordination compound molecules may be affected by several factors, such as the performance of the ligands, the property of the central atoms, anion effects, solvent effects, and so on[50-59]. Transition metal Salamo-type coordination compounds have aroused widespread concerns for their photophysical properties [60-66]. Previous studies have been carried out on the mononuclear coordination compounds $[67,68]$. However, there are relatively few studies on multinuclear Salamo-type bisoxime coordination compounds. Though mono-, di-, and trinuclear $\mathrm{Co}(\mathrm{II})$ coordination compounds have been reported [69-71], the study of the synthesis and corresponding properties of multinuclear Co(II) coordination compounds are relatively few [72-74]. 
The purpose of the present work is the structural characterization of polynuclear Co(II) coordination compounds derived of nonsymmetrical Salamo-type bisoxime ligands. Here, the ligand $\mathrm{H}_{4} \mathrm{~L}$ and its corresponding hexanuclear $\mathrm{Co}(\mathrm{II})$ coordination compound $\left(\left[\left\{\mathrm{Co}_{3}(\mathrm{HL})(\mathrm{MeO})(\mathrm{MeOH})_{2}(\mathrm{OAc})_{2}\right\}_{2}\right] \cdot 2 \mathrm{MeOH}\right)$ was gained. In addition, the supramolecular buildings and photophysical behaviors of the $\mathrm{Co}(\mathrm{II})$ coordination compound are discussed.

\section{Experimental}

\subsection{Materials and Physical Measurements}

All chemicals were of analytical reagent grade. Elemental analyses for $\mathrm{C}, \mathrm{H}$, and $\mathrm{N}$ were gained using a GmbH VarioEL V3.00 automatic elemental analysis instrument (Berlin, Germany), elemental analysis for Co was detected by an IRIS ER/S.WP-1 ICP atomic emission spectrometer (Berlin, Germany). UV-vis and fluorescence spectra were measured on a Shimadzu UV-2550 spectrometer (Shimadzu, Japan) and F-7000 FL spectrometer (Hitachi, Tokyo, Japan), respectively. Infrared (IR) spectra were performed on a VERTEX-70 FT-IR spectrophotometer (Bruker, Billerica, MA, USA), with samples prepared as $\mathrm{KBr}\left(500-4000 \mathrm{~cm}^{-1}\right) .{ }^{1} \mathrm{H}-\mathrm{NMR}$ spectra were carried out via German Bruker AVANCE DRX-400 spectroscopy (Bruker AVANCE, Billerica, MA, USA). Single-crystal X-ray structure determination was performed on a SuperNova Dual ( $\mathrm{Cu}$ at zero) Eos four-circle diffractometer. Melting points were measured via a microscopic melting point apparatus (Beijing Taike Instrument Limited Company, Beijing, China).

\subsection{Preparations and Characterizations}

\subsubsection{Preparation and Characterization of $\mathrm{H}_{4} \mathrm{~L}$}

1,2-Bis(aminooxy)ethane was obtained by an early reported method [75-77]. Yield: 85.2\%. Anal. Calcd for $\mathrm{C}_{2} \mathrm{H}_{8} \mathrm{~N}_{2} \mathrm{O}_{2}$ (\%): C, 26.08; $\mathrm{H}, 8.76 ; \mathrm{N}, 30.42$. Found: $\mathrm{C}, 25.98 ; \mathrm{H}, 8.90 ; \mathrm{N}, 30.38$. The synthetic route to $\mathrm{H}_{4} \mathrm{~L}$ is depicted in Scheme 1.

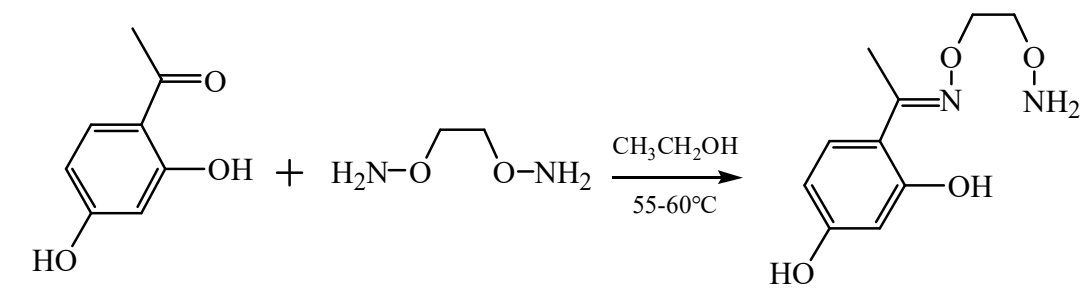<smiles>C/C(=N\OCCO/N=C/c1cccc(O)c1O)c1ccc(O)cc1O</smiles>

Scheme 1. Synthetic route to $\mathrm{H}_{4} \mathrm{~L}$.

Monooxime compound was obtained by a modified method [32]. After purification by column chromatography, single condensation product of ethylene oxide single condensing 1,2-diamine-2,4-dihydroxyacetophenone was obtained. Reaction of ethylene oxide single condensing 1,2-diamine-2,4-dihydroxyacetophenone with 2,3-dihydroxybenzaldehyde provided one nonsymmetrical Salamo-type compound $\mathrm{H}_{4} \mathrm{~L}$. Yield: $88.7 \%$. Anal. Calcd. for $\mathrm{C}_{17} \mathrm{H}_{18} \mathrm{~N}_{2} \mathrm{O}_{6}(\%)$ : $\mathrm{C}$, 58.89; H, 4.82; N, 8.17. Found: C, 59.23; H, 4.91; N, 8.01. ${ }^{1} \mathrm{H}-\mathrm{NMR}\left(400 \mathrm{MHz}, \mathrm{CDCl}_{3}\right): \delta=2.28(\mathrm{~s}, 3 \mathrm{H}$, $\left.-\mathrm{CH}_{3}\right), 4.45-4.53\left(\mathrm{~m}, 4 \mathrm{H},-\mathrm{CH}_{2}-\mathrm{CH}_{2}-\right), 5.12(\mathrm{~s}, 1 \mathrm{H}, \mathrm{O}-\mathrm{H}), 5.59(\mathrm{~s}, 1 \mathrm{H}, \mathrm{O}-\mathrm{H}), 6.42(\mathrm{~m}, 2 \mathrm{H}, \mathrm{Ar}-\mathrm{H}), 6.75(\mathrm{dd}$, 
$J=1.52,1.28 \mathrm{~Hz}, 1 \mathrm{H}, \mathrm{Ar}-\mathrm{H}), 6.85(\mathrm{t}, J=1.36,1.20,1.16 \mathrm{~Hz}, 1 \mathrm{H}, \mathrm{Ar}-\mathrm{H}), 6.97(\mathrm{dd}, J=1.56,1.68 \mathrm{~Hz}, 1 \mathrm{H}$, $\mathrm{Ar}-\mathrm{H}), 7.28(\mathrm{~d}, J=9.12 \mathrm{~Hz}, 1 \mathrm{H}, \mathrm{Ar}-\mathrm{H}), 8.22(\mathrm{~s}, 1 \mathrm{H}, \mathrm{N}=\mathrm{C}-\mathrm{H}), 9.91(\mathrm{~s}, 1 \mathrm{H}, \mathrm{O}-\mathrm{H}), 11.38(\mathrm{~s}, 1 \mathrm{H}, \mathrm{O}-\mathrm{H}) \mathrm{ppm}$.

\subsubsection{Preparation and Characterizationof the Co(II) Coordination Compound}

A methanol solution $(3 \mathrm{~mL})$ of $\mathrm{Co}(\mathrm{OAc})_{2} \cdot 4 \mathrm{H}_{2} \mathrm{O}(37.3 \mathrm{mg}, 0.150 \mathrm{mmol})$ was added dropwise to a methanol solution $(4 \mathrm{~mL})$ of $\mathrm{H}_{4} \mathrm{~L}(17.3 \mathrm{mg}, 0.050 \mathrm{mmol})$. The color of the mixed solution immediately turned to brown, and then continuing stirring for $2 \mathrm{~h}$. The resultant solution was allowed to slowly evaporate at room temperature. Brown diamond single crystals suitable for $\mathrm{X}$-ray diffraction studies were obtained after four weeks. Yield: $68.5 \%$. Anal. Calcd. for $\mathrm{C}_{50} \mathrm{H}_{72} \mathrm{Co}_{6} \mathrm{~N}_{4} \mathrm{O}_{28}(\%): \mathrm{C}, 39.23 ; \mathrm{H}, 4.74$; N, 3.66; Co, 26.10. Found: C, 39.62; H, 4.57; N, 3.38; Co, 25.78.

\subsection{X-ray Structure Determination of the Co(II) Coordination Compound}

X-ray diffraction data were collected on a SuperNova Dual ( $\mathrm{Cu}$ at zero) Eos four-circle diffractometer via graphite monochromatized Mo- $K_{\alpha}$ radiation $(\lambda=0.71073 \AA)$ at $298(2) \mathrm{K}$. Unit cell parameters were determined by least squares analysis. The LP factor and semi-empirical absorption corrections were applied to the intensity data. The structure was solved by the direct method (SHELXS-97), and all hydrogen atoms were added theoretically. All non-hydrogen atoms were refined anisotropically using a full-matrix least-squares procedure on $F^{2}$ with SHELXL-97. Anisotropic thermal parameters were assigned to all non-hydrogen atoms. The hydrogen atoms were generated geometrically. Some reflections with high intensities, which made the detector overflow, were automatically omitted by the diffractometer. So some reflections were missing. The crystallographic and structural refinement data for the Co(II) coordination compound are summed in Table 1. Supplementary crystallographic data for this paper have been deposited at the Cambridge Crystallographic Data Centre (1519431) and can be obtained free of charge viawww.ccdc.cam.ac.uk/conts/retrieving.html.

Table 1. Crystallographic and structural refinement data for the Co(II) coordination compound.

\begin{tabular}{|c|c|}
\hline Molecular formula & $\mathrm{C}_{50} \mathrm{H}_{72} \mathrm{Co}_{6} \mathrm{~N}_{4} \mathrm{O}_{28}$ \\
\hline Molecular weight $/ \mathrm{g} \cdot \mathrm{mol}^{-1}$ & 1530.63 \\
\hline Color & Light-brown \\
\hline Habit & Block-shaped \\
\hline Crystal size (mm) & $0.21 \times 0.23 \times 0.31$ \\
\hline Crystal system & Monoclinic \\
\hline Space group & $C 2 / c$ \\
\hline \multicolumn{2}{|l|}{ Unit cell dimension } \\
\hline$a(\AA)$ & $17.9738(8)$ \\
\hline$b(\AA)$ & $15.0717(8)$ \\
\hline$c(\AA)$ & $24.5022(14)$ \\
\hline$\alpha\left(^{\circ}\right)$ & 90 \\
\hline$\beta\left(\left(^{\circ}\right)\right.$ & $102.627(5)$ \\
\hline$\gamma\left(\left(^{\circ}\right)\right.$ & 90 \\
\hline$V\left(\AA^{3}\right)$ & $6477.0(6)$ \\
\hline$Z$ & 4 \\
\hline$D_{c}\left(\mathrm{~g} \cdot \mathrm{cm}^{-3}\right)$ & 1.570 \\
\hline$\mu\left(\mathrm{mm}^{-1}\right)$ & 1.585 \\
\hline$F(000)$ & 3144 \\
\hline$\theta$ range for data collection $\left(^{\circ}\right)$ & $3.2-26.0$ \\
\hline Index ranges & $-22 \leq h \leq 22,-18 \leq k \leq 18,-29 \leq l \leq 30$ \\
\hline Reflections collected & 14,114 \\
\hline Completeness to $\theta=25.00(\%)$ & 99.7 \\
\hline Data/restraints/parameters & $6381 / 0 / 415$ \\
\hline Final Rindices $(I>2 \sigma(I))$ & $R_{1}=0.0504, w R_{2}=0.1227$ \\
\hline$R$ indices(all data) & $R_{1}=0.0694, w R_{2}=0.1111$ \\
\hline Largest diff. peak and hole $\left(\mathrm{e} \cdot \AA^{-3}\right)$ & 0.51 and -0.43 \\
\hline
\end{tabular}




\section{Results and Discussion}

\subsection{Description of the Crystal Structure}

Asdepicted in Figure 1, the centrosymmetric neutral homomultinuclear Co(II) coordination compound has been revealedby single crystal X-raydiffraction (Table 2). It crystallizes in the monoclinic crystal system, space group $C 2 / c$, and consists of six $\mathrm{Co}$ (II) atoms, two (HL) ${ }^{3-}$ units, two $\mu_{2}$-acetato ions, two bidentate chelating acetate ions, two coordinated deprotonated methanol molecules, four coordinated methanol molecules, and two crystallizing methanol molecules. This 6:2 (Co(II) atom: Ligand) type of Co(II) coordination compound is unprecedented in the early reported Salamo-based Co(II) coordination compounds bearing the structures of 1:1 [44,58], 3:2 [44,47,74], 4:2 [15] and 8:4 [78]. (Figure 1) The whole coordination compound molecule is symmetrical and therefore only shows Co1, $\mathrm{Co} 2$, and $\mathrm{Co} 3$ coordination situation can explain the structure of the whole coordination compound. The terminal Co1 atom is located in the $\mathrm{N}_{2} \mathrm{O}_{2}$ coordination sphere, the axial position is occupied by two oxygen atoms from two coordinated methanol molecules. The $\mathrm{Co} 2$ atom is surrounded by quadruple phenol oxygen atoms $\left(\mathrm{O} 1, \mathrm{O} 5, \mathrm{O} 7\right.$ and $\mathrm{O} 7^{\# 1}$ ) from two $(\mathrm{HL})^{3-}$ moieties, one $\mu_{2}$-acetato oxygen atom $(\mathrm{O} 2)$ and one deprotonated methanol oxygen atom (O6). Meanwhile, the Co3 atom coordinates with one phenol oxygen atom (O7) from one (HL) $)^{3-}$ moiety, one $\mu_{2}$-acetato oxygen atom (O13), two oxygen atoms (O6 and $\mathrm{O}^{\# 1}$ ) of two coordinated deprotonated methanol molecules and two bidentate chelate acetato oxygen atoms (O11 and O12) which adopt a familiar Co-O-C-O-Co fashion. Each Co(II) atom bears a hexacoordinate sphere and possesses distorted $\mathrm{CoO}_{6}$ or $\mathrm{CoO}_{4} \mathrm{~N}_{2}$ octahedrons. The hydrogen atoms of two $\mu_{2}$-acetato ions (H10B, H10C, H10D and H10B ${ }^{\# 1}, \mathrm{H}_{10 C}^{\# 1}, \mathrm{H}{ }^{\# D^{\# 1}}$; H22A, H22B, H22C and $\mathrm{H} 22 \mathrm{~A}^{\# 1}, \mathrm{H} 22 \mathrm{~B}^{\# 1}, \mathrm{H} 22 \mathrm{C}^{\# 1}$ ) are disordered equally over two different positions, which were allowed for during refinement.

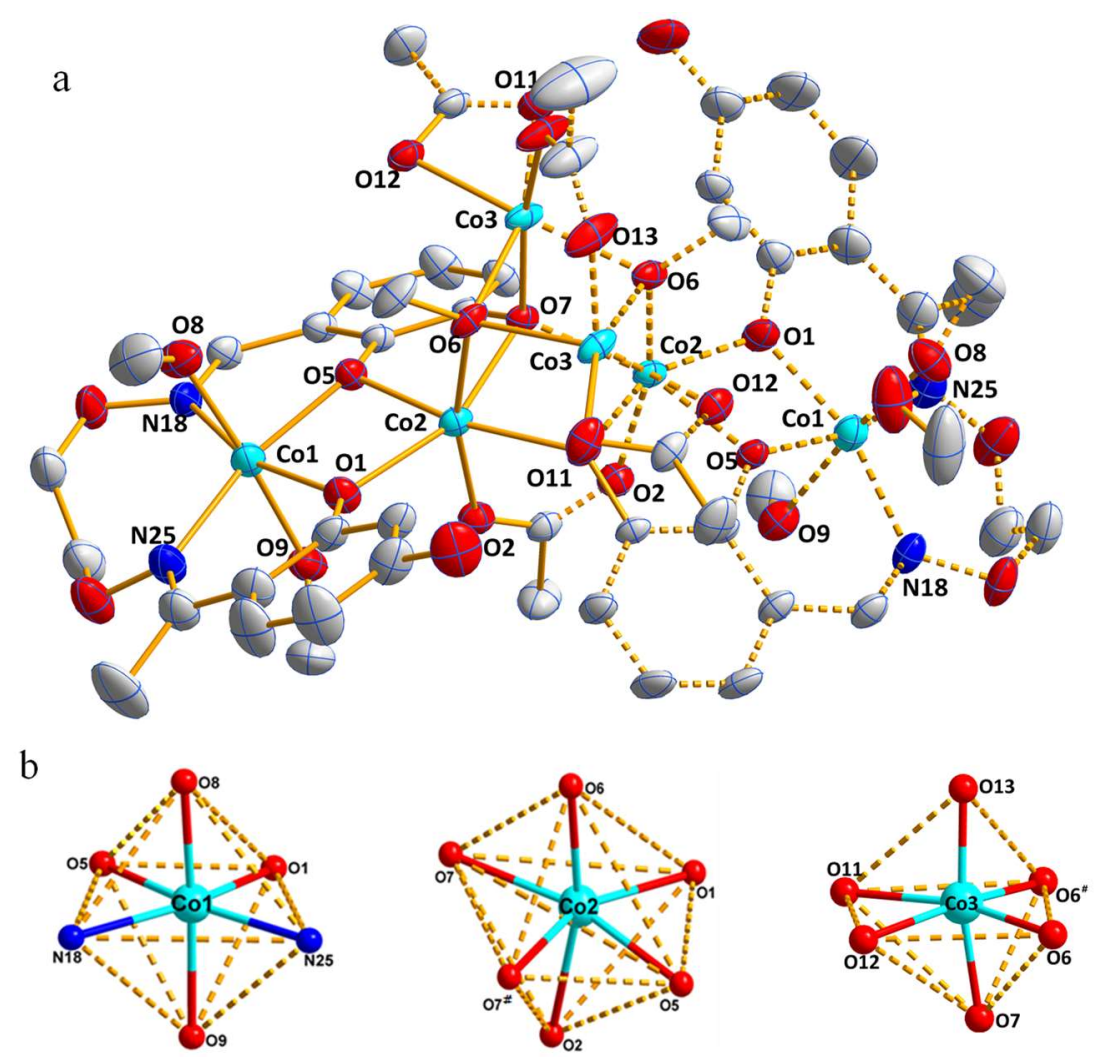

Figure 1. (a) Crystal structure and atom numberings of the Co(II) coordination compound; (b) Coordination polyhedrons for Co(II) atoms. 
Table 2. Selected bond lengths $(\AA)$ and angles $\left(^{\circ}\right)$ for the Co(II) coordination compound.

\begin{tabular}{|c|c|c|c|c|c|}
\hline Bond & Dist. & Bond & Dist. & Bond & Dist. \\
\hline Co2-O1 & $2.117(3)$ & Co3-O6 & $2.061(2)$ & Co1-O1 & $2.019(3)$ \\
\hline $\mathrm{Co} 2-\mathrm{O} 2$ & $2.141(3)$ & $\mathrm{Co} 3-\mathrm{O}^{\# 1}$ & $2.089(3)$ & Co1-O5 & $2.025(2)$ \\
\hline Co2-O5 & $2.029(2)$ & Co3-O7 & $2.150(2)$ & Co1-O8 & $2.112(3)$ \\
\hline $\mathrm{Co} 2-\mathrm{O} 6$ & $2.067(3)$ & Co3-O11 & $2.208(3)$ & Co1-O9 & $2.214(3)$ \\
\hline $\mathrm{Co} 2-\mathrm{O} 7$ & $2.073(2)$ & Co3-O12 & $2.116(3)$ & Co1-N18 & $2.165(3)$ \\
\hline $\mathrm{Co} 2-\mathrm{O}^{\# 1}$ & $2.209(2)$ & $\mathrm{Co3}-\mathrm{O} 13$ & $2.041(3)$ & Co1-N25 & $2.113(4)$ \\
\hline $\mathrm{Co} 3-\mathrm{Co}^{\# 1}$ & $2.9071(10)$ & Co3-C18 & $2.511(4)$ & $\mathrm{Co}^{\# 1}-\mathrm{O} 6$ & $2.089(3)$ \\
\hline $\mathrm{Co} 2^{\# 1}-\mathrm{O} 7$ & $2.209(2)$ & & & & \\
\hline Bond & Angles & Bond & Angles & Bond & Angles \\
\hline $\mathrm{O} 1-\mathrm{Co} 2-\mathrm{O} 2$ & $90.80(11)$ & O11-Co3-C18 & $30.08(12)$ & $\mathrm{Co} 3-\mathrm{O} 6-\mathrm{Co} 2$ & $101.80(10)$ \\
\hline $\mathrm{O} 1-\mathrm{Co} 2-\mathrm{O}^{\# 1}$ & $153.79(9)$ & O12-Co3-Co3 ${ }^{\# 1}$ & $146.40(9)$ & $\mathrm{Co} 3-\mathrm{O} 6-\mathrm{Co}^{\# 1}$ & $88.94(11)$ \\
\hline $\mathrm{O} 2-\mathrm{Co} 2-\mathrm{O}^{\# 1}$ & $88.85(10)$ & O13-Co3-O6 & $91.72(11)$ & C20-O6-Co2 & $121.2(3)$ \\
\hline O5-Co2-O1 & $76.15(10)$ & O13-Co3-O6 & $93.82(14)$ & $\mathrm{C} 20-\mathrm{O} 6-\mathrm{Co} 3$ & $122.4(2)$ \\
\hline $\mathrm{O} 5-\mathrm{Co} 2-\mathrm{O} 2$ & $86.34(10)$ & O13-Co3-O7 & $170.00(10)$ & $\mathrm{C} 20-\mathrm{O} 6-\mathrm{Co}^{\# 1}$ & $115.2(3)$ \\
\hline O5-Co2-O6 & 101.62(10) & O13-Co3-O11 & $92.80(13)$ & $\mathrm{Co} 2-\mathrm{O} 7-\mathrm{Co} 2^{\# 1}$ & $92.10(9)$ \\
\hline $\mathrm{O} 5-\mathrm{Co} 2-\mathrm{O}^{\# 1}$ & $77.67(9)$ & O13-Co3-O12 & $98.46(11)$ & $\mathrm{Co} 2-\mathrm{O} 7-\mathrm{Co} 3$ & $98.68(9)$ \\
\hline O5-Co2-O7 & $163.15(10)$ & O13-Co3-C18 & $97.74(13)$ & $\mathrm{Co} 3-\mathrm{O} 7-\mathrm{Co}_{2}^{\# 1}$ & $94.82(9)$ \\
\hline O6-Co2-O1 & $102.51(11)$ & $\mathrm{C} 18-\mathrm{Co} 3-\mathrm{Co}^{\# 1}$ & $176.17(11)$ & $\mathrm{C} 15-\mathrm{O}^{\# 1}-\mathrm{Co}^{\# 1}$ & $105.67(19)$ \\
\hline $\mathrm{O} 6-\mathrm{Co} 2-\mathrm{O} 2$ & $165.75(10)$ & O1-Co1-O5 & $78.47(10)$ & $\mathrm{C} 15-\mathrm{O} 7-\mathrm{Co}^{\# 1}$ & 133.1(2) \\
\hline O6-Co2-O7 & $80.59(9)$ & O1-Co1-O8 & $98.60(14)$ & $\mathrm{C} 15-\mathrm{O} 7-\mathrm{Co}^{\# 1}$ & $121.9(2)$ \\
\hline $\mathrm{O} 6-\mathrm{Co} 2-\mathrm{O}^{\# 1}$ & $81.45(10)$ & O1-Co1-O9 & 87.35(11) & Co1-O8-H8 & $111(4)$ \\
\hline O7-Co2-O1 & $119.97(10)$ & O1-Co1-N18 & $161.07(12)$ & C24-O8-Co1 & $132.9(3)$ \\
\hline $\mathrm{O} 7-\mathrm{Co} 2-\mathrm{O} 2$ & $88.43(10)$ & O1-Co1-N25 & $86.34(13)$ & Co1-O9-H9 & $98(4)$ \\
\hline $\mathrm{O} 7-\mathrm{Co} 2-\mathrm{O}^{\# 1}$ & $86.23(9)$ & O5-Co1-O8 & $91.60(11)$ & C23-O9-Co1 & $122.5(3)$ \\
\hline $\mathrm{O}^{\# 1}-\mathrm{Co} 3-\mathrm{Co}^{\# 1}$ & $45.14(7)$ & O5-Co1-O9 & $90.46(11)$ & C18-O11-Co3 & $88.4(3)$ \\
\hline $\mathrm{O} 6-\mathrm{Co} 3-\mathrm{Co}^{\# 1}$ & $45.92(8)$ & O5-Co1-N18 & $83.09(11)$ & $\mathrm{C} 18-\mathrm{O} 12-\mathrm{Co} 3$ & $92.5(2)$ \\
\hline O6-Co3-O6 $\# 1$ & $87.96(11)$ & O5-Co1-N25 & $164.65(13)$ & C10-O13-Co3 & $126.2(4)$ \\
\hline $\mathrm{O} 6-\mathrm{Co} 3-\mathrm{O}^{\# 1}$ & $82.40(10)$ & O8-Co1-O9 & $173.99(13)$ & O4-N18-Co1 & $124.2(2)$ \\
\hline O6-Co3-O7 & $78.93(9)$ & O8-Co1-N18 & $86.09(14)$ & C10-N18-Co1 & $127.3(3)$ \\
\hline O6-Co3-O11 & $161.75(10)$ & O8-Co1-N25 & $92.93(14)$ & O3-N25-Co1 & $120.9(3)$ \\
\hline O6-Co3-O11 & $108.83(11)$ & N18-Co1-O9 & $88.55(13)$ & C7-N25-Co1 & $128.9(3)$ \\
\hline O6-Co3-O12\#1 & $101.92(11)$ & N25-Co1-O9 & $86.53(14)$ & Co1-O5-Co2 & $103.33(11)$ \\
\hline O6-Co3-O12 & $165.23(11)$ & N25-Co1-N18 & $111.85(14)$ & $\mathrm{C} 16-\mathrm{O} 5-\mathrm{Co} 2$ & $112.6(2)$ \\
\hline O6-Co3-C18 & $137.80(13)$ & Co1-O1-Co2 & $100.48(11)$ & C16-O5-Co1 & $132.1(2)$ \\
\hline $\mathrm{O} 6-\mathrm{Co}^{\# 1}-\mathrm{C} 18$ & $131.87(12)$ & $\mathrm{C} 1-\mathrm{O} 1-\mathrm{Co} 2$ & $128.5(3)$ & $\mathrm{Co} 2-\mathrm{O} 6-\mathrm{Co}^{\# 1}$ & $101.10(11)$ \\
\hline $\mathrm{O} 7-\mathrm{Co} 3-\mathrm{Co}^{\# 1}$ & $90.21(6)$ & $\mathrm{C} 1-\mathrm{O} 1-\mathrm{Co} 1$ & $129.0(2)$ & $\mathrm{O} 12-\mathrm{Co} 3-\mathrm{O} 7$ & $91.39(10)$ \\
\hline O7-Co3-O11 & $93.59(11)$ & $\mathrm{C} 21-\mathrm{O} 2-\mathrm{Co} 2$ & $128.6(3)$ & O12-Co3-O11 & $60.23(11)$ \\
\hline O7-Co3-C18 & $91.63(12)$ & O12-Co3-O7 & $91.39(10)$ & O12-Co3-O11 & $60.23(11)$ \\
\hline O11-Co3-Co3 & $153.05(8)$ & & & & \\
\hline
\end{tabular}

Symmetry transformations used to generate equivalent atoms: ${ }^{\# 1}-\mathrm{x}+1,-\mathrm{y}+1,-\mathrm{z}+1$.

In the crystal structure of the $\mathrm{Co}(\mathrm{II})$ coordination compound, there are five significant

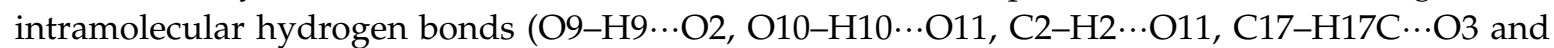
$\mathrm{C} 8-\mathrm{H} 8 \mathrm{~B} \cdots \mathrm{O} 9$ ) and two intermolecular $\mathrm{C} 12-\mathrm{H} 12 \cdots \mathrm{O} 13$ and $\mathrm{O} 14-\mathrm{H} 14 \mathrm{~A} \cdots \mathrm{O} 12$ interactions (Figure 2). In addition, there is a pair of $\pi \cdots \pi$ interactions $\mathrm{Cg} 1 \cdots \mathrm{Cg} 1(\mathrm{Cg} 1=\mathrm{C} 1-\mathrm{C} 2-\mathrm{C} 3-\mathrm{C} 4-\mathrm{C} 5-\mathrm{C} 6)$ (Figure 3$)$ in the $\mathrm{Co}(\mathrm{II})$ coordination compound [79]. Meanwhile, the hydrogen bonds interactions existing in the Co(II) coordination compound are described in graph sets (Figure 4) [80]. Furthermore, the molecules are linked by intermolecular interactions form a 2D infinite planar (Figure 5). Putative hydrogen bonds for the Co(II) coordination compoundare listed in Table 3. 
a
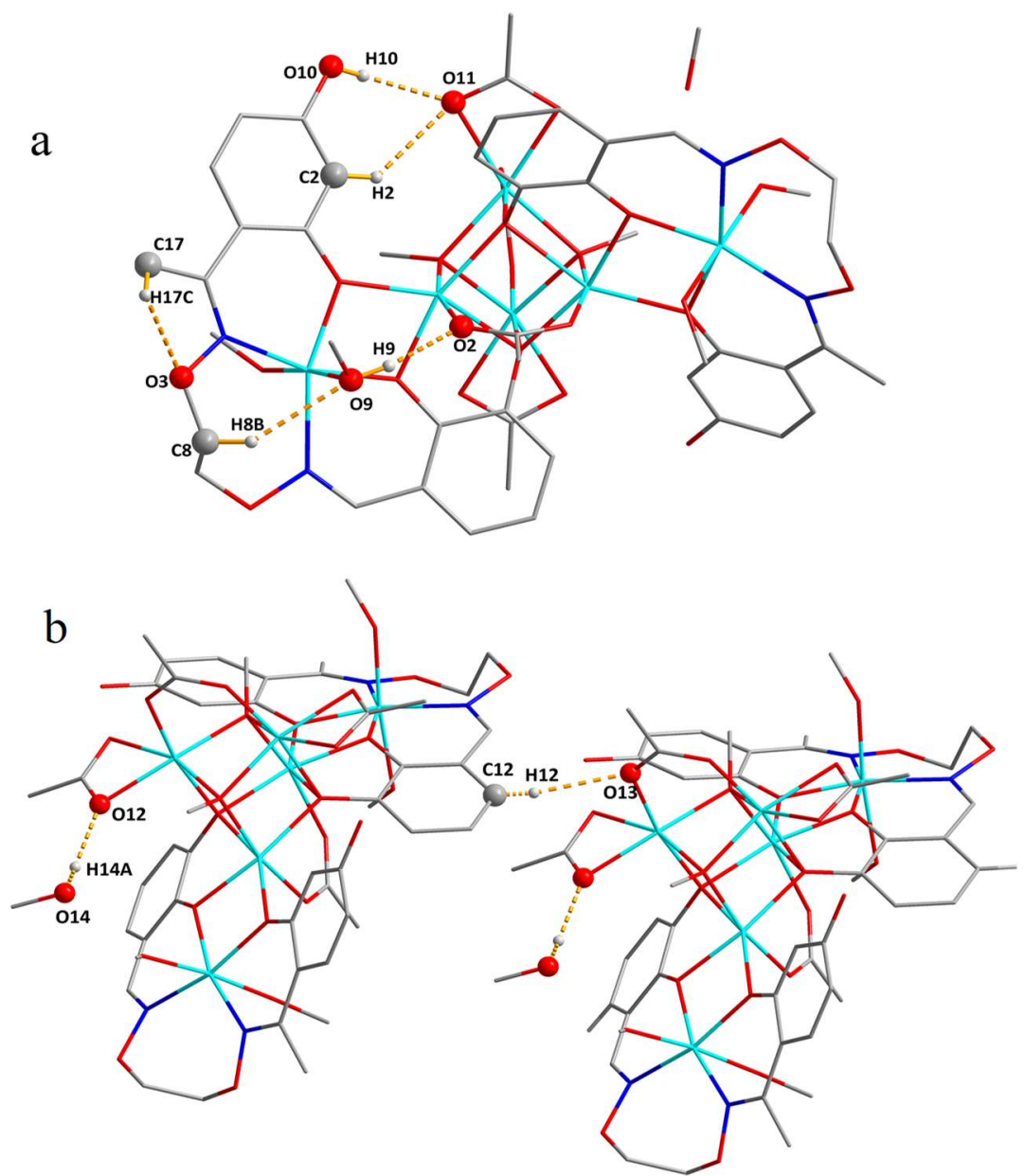

Figure 2. View of the intramolecular (a) and intermolecular (b) interactions of the $\mathrm{Co}$ (II) coordination compound.

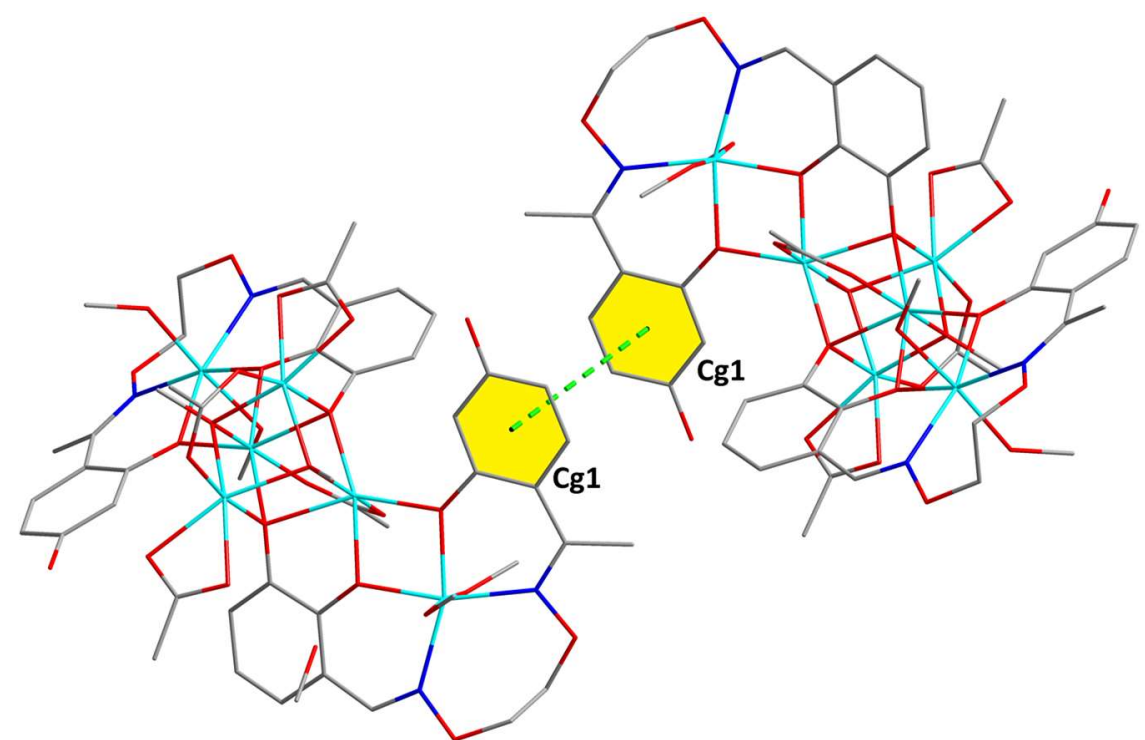

Figure 3. $\pi \cdots \pi$ stacking interactions of the $\mathrm{Co}(\mathrm{II})$ coordination compound. 


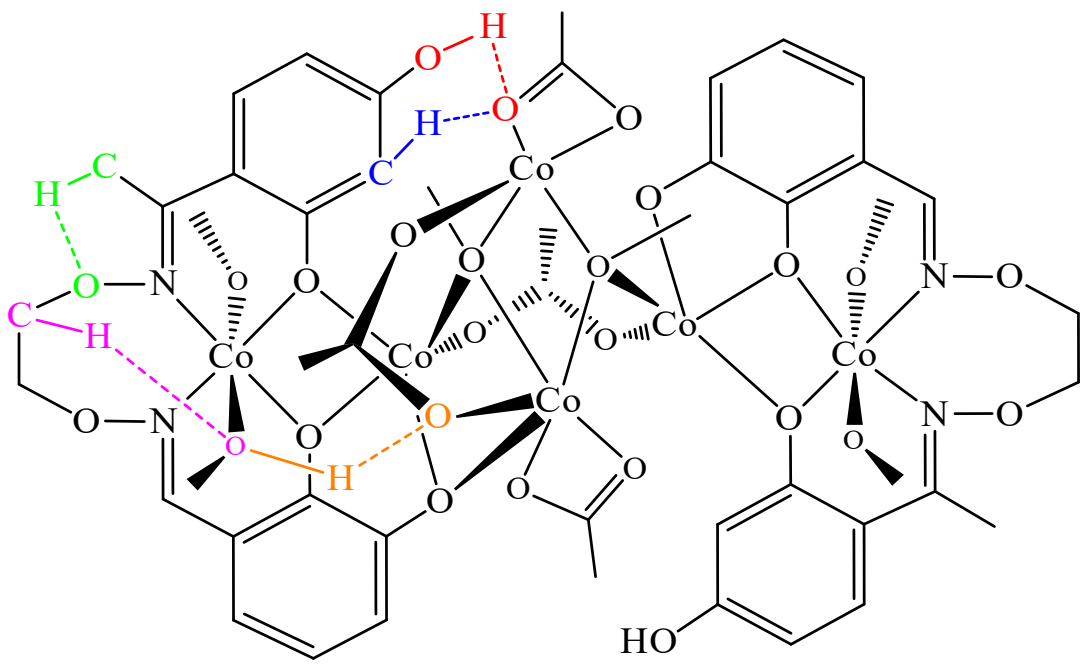<smiles>Cc1[nH]o[n+]1C(=O)O</smiles>

S(5)<smiles></smiles>

$\mathrm{S}(6)$<smiles>O1[GeH2]O[GeH2]O[GeH2]O[GeH2]1</smiles>

S(8)<smiles></smiles>

S(6)

Figure 4. Graph set assignments for the Co(II) coordination compound.

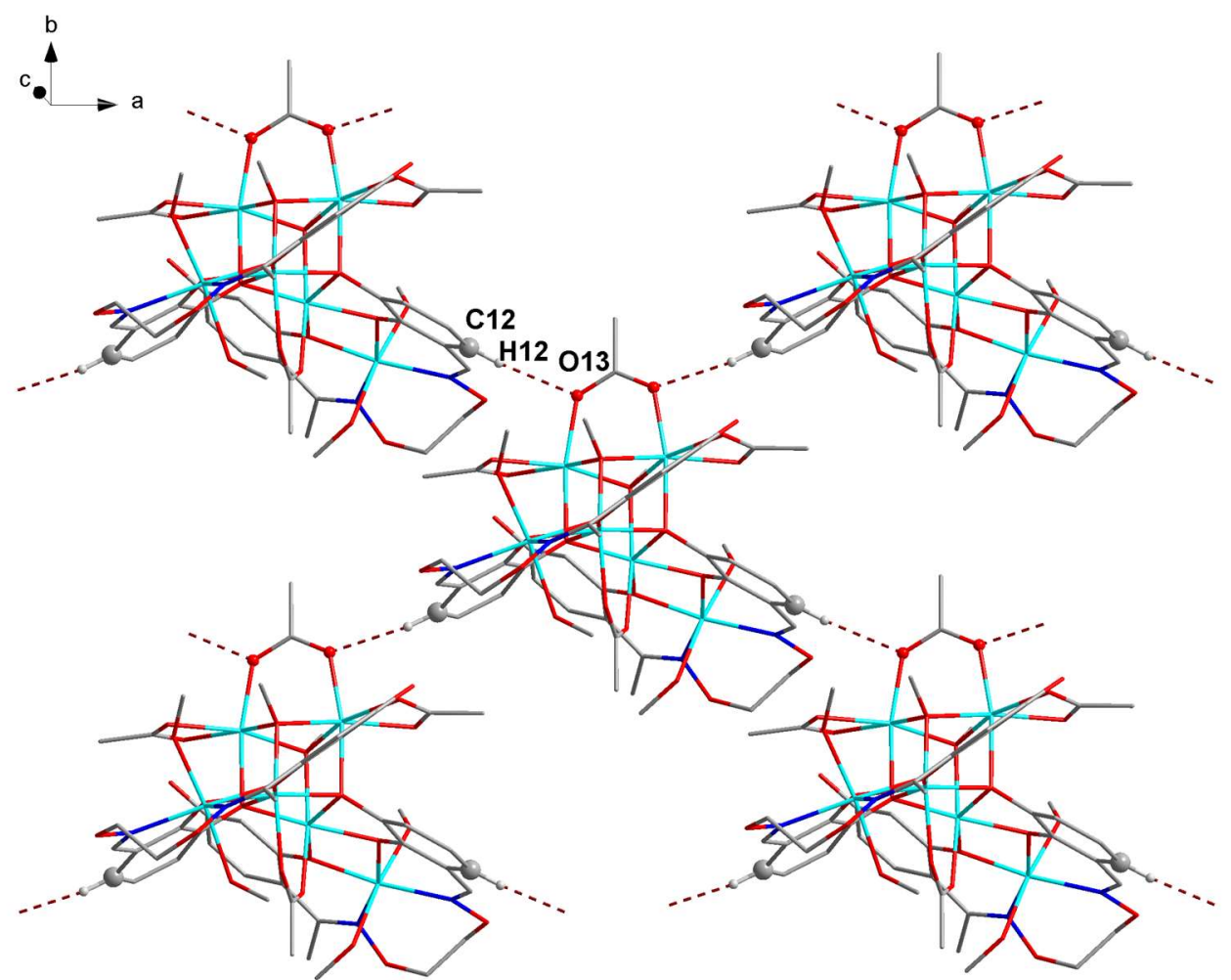

Figure 5. View of the 2D layered structure of the Co(II) coordination compound. 
Table 3. Putative hydrogen bondings $(\AA),\left(^{\circ}\right)$ in the Co(II) coordination compound.

\begin{tabular}{|c|c|c|c|c|c|}
\hline D-H $\cdots A$ & $\mathrm{~d}(\mathrm{D}-\mathrm{H})$ & $\mathrm{d}(\mathrm{H} \cdots \mathrm{A})$ & $d(D \cdots A)$ & $\angle \mathrm{D}-\mathrm{H} \cdots \mathrm{A}$ & Symmetry Code \\
\hline $\mathrm{C} 12-\mathrm{H} 12 \cdots \mathrm{O} 13$ & 0.93 & 2.35 & $3.275(5)$ & 171 & $-1 / 2+x,-1 / 2+y, z$ \\
\hline $\mathrm{O} 9-\mathrm{H} 9 \cdots \mathrm{O} 2$ & 0.85 & 1.77 & $2.616(4)$ & 171 & \\
\hline $\mathrm{O} 10-\mathrm{H} 10 \cdots \mathrm{O} 11$ & 0.82 & 1.99 & $2.759(5)$ & 157 & \\
\hline 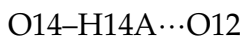 & 0.82 & 1.90 & $2.718(5)$ & 175 & $-x, y, 1 / 2-z$ \\
\hline $\mathrm{C} 2-\mathrm{H} 2 \cdots \mathrm{O} 11$ & 0.93 & 2.46 & $3.191(5)$ & 135 & \\
\hline C $8-H 8 B \cdots O 9$ & 0.97 & 2.45 & $3.291(6)$ & 145 & \\
\hline C17-H17C ‥O3 & 0.96 & 2.19 & $2.543(8)$ & 100 & \\
\hline
\end{tabular}

\subsection{IR Spectroscopy}

IR spectra (Table 4) of $\mathrm{H}_{4} \mathrm{~L}$ and its corresponding $\mathrm{Co}(\mathrm{II})$ coordination compound exhibit different bands in the region of $400-4000 \mathrm{~cm}^{-1}$. $\mathrm{H}_{4} \mathrm{~L}$ shows a characteristic $\mathrm{C}=\mathrm{N}$ stretching band at $1630 \mathrm{~cm}^{-1}$, while the $\mathrm{C}=\mathrm{N}$ stretching band of the $\mathrm{Co}(\mathrm{II})$ coordination compound appears at $1592 \mathrm{~cm}^{-1}$ [64]. For the ligand $\mathrm{H}_{4} \mathrm{~L}$, the Ar-O stretching band appears at $1260 \mathrm{~cm}^{-1}$, which is observed at $1255 \mathrm{~cm}^{-1}$ for the $\mathrm{Co}$ (II) coordination compound. The characteristic $\mathrm{C}=\mathrm{N}$ and $\mathrm{Ar}-\mathrm{O}$ stretching frequencies are shifted to lower frequencies, exhibiting that the $\mathrm{Co}-\mathrm{N}$ and $\mathrm{Co}-\mathrm{O}$ bonds are formed $[69,71]$. The $\mathrm{O}-\mathrm{H}$ stretching frequency of $\mathrm{H}_{4} \mathrm{~L}$ appears at $3373 \mathrm{~cm}^{-1}$, whereas the $\mathrm{Co}$ (II) coordination compound shows a stretching band at $3421 \mathrm{~cm}^{-1}$, which is attributed to vibrations of the coordinated methanol molecules. For the $\mathrm{Co}$ (II) coordination compound, the $v_{(\mathrm{Co}-\mathrm{O})}$ and $v_{(\mathrm{Co}-\mathrm{N})}$ frequencies are observed at 463 and $519 \mathrm{~cm}^{-1}$, respectively [74,81].

Table 4. Major IR bands for $\mathrm{H}_{4} \mathrm{~L}$ and its $\mathrm{Co}(\mathrm{II})$ coordination compound( $\left.\mathrm{cm}^{-1}\right)$.

\begin{tabular}{cccccc}
\hline Compound & $v_{(\mathrm{O}-\mathrm{H})}$ & $\boldsymbol{v}_{(\mathrm{C}=\mathrm{N})}$ & $\boldsymbol{v}_{(\mathrm{Ar}-\mathrm{O})}$ & $\boldsymbol{v}_{(\mathrm{Co}-\mathrm{O})}$ & $v_{(\mathrm{Co}-\mathrm{N})}$ \\
\hline $\mathrm{H}_{4} \mathrm{~L}$ & 3373 & 1630 & 1260 & - & - \\
$\mathrm{Co}(\mathrm{II})$ & 3421 & 1592 & 1255 & 463 & 519 \\
\hline
\end{tabular}

\subsection{UV-Vis Spectroscopy}

The UV-vis spectra of $\mathrm{H}_{4} \mathrm{~L}$ and its $\mathrm{Co}(\mathrm{II})$ coordination compound were measured in $1 \times 10^{-6} \mathrm{~mol} \cdot \mathrm{L}^{-1} \mathrm{CH}_{2} \mathrm{Cl}_{2}$ solution. It is noteworthy that the absorption peaks of the $\mathrm{Co}(\mathrm{II})$ coordination compound are evidently different from those of $\mathrm{H}_{4} \mathrm{~L}$ (Figure 6). Electronic absorption spectrum of $\mathrm{H}_{4} \mathrm{~L}$ composes of two relatively intense peaks centered at 275 and $299 \mathrm{~nm}$, attributed to the intra-ligand $\pi-\pi^{*}$ transitions of the benzene rings and the $\mathrm{C}=\mathrm{N}$ bonds, respectively. Compared with $\mathrm{H}_{4} \mathrm{~L}$, the absorption peaks of the $\mathrm{Co}$ (II) coordination compound appears at 277 and $311 \mathrm{~nm}$, which are bathochromically shifted by ca. 2 and $12 \mathrm{~nm}$, exhibiting the $\mathrm{Co}$ (II) ions have coordinated with $\mathrm{H}_{4} \mathrm{~L}$. The new peak of the $\mathrm{Co}$ (II) coordination compound appears at ca. $385 \mathrm{~nm}$, attributed to $\mathrm{L} \rightarrow \mathrm{M}$ charge-transfer transition $[82,83]$. 


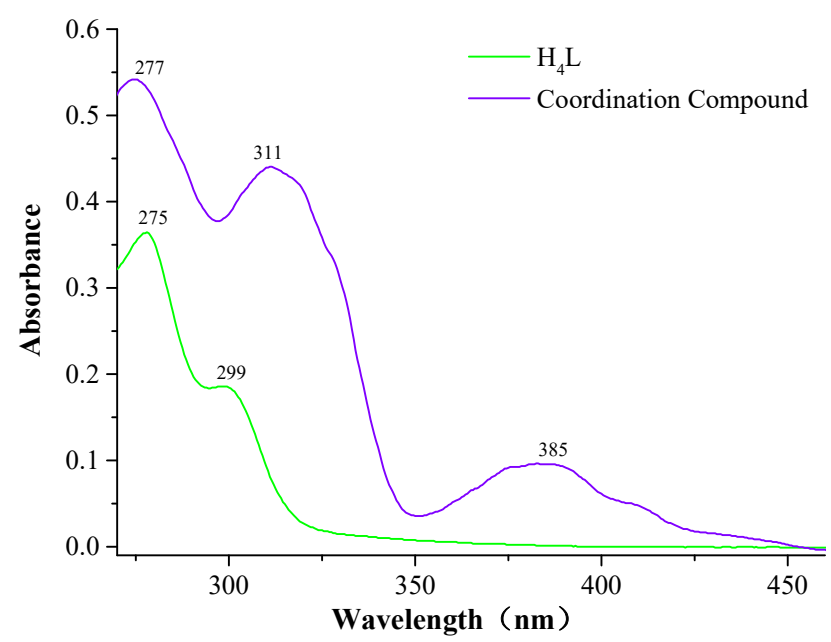

Figure 6. UV-vis spectra of $\mathrm{H}_{4} \mathrm{~L}$ and its $\mathrm{Co}(\mathrm{II})$ coordination compound in $\mathrm{CH}_{2} \mathrm{Cl}_{2}\left(1 \times 10^{-6} \mathrm{M}\right)$.

\subsection{Fluorescence Properties}

The fluorescence properties of $\mathrm{H}_{4} \mathrm{~L}$ and its corresponding Co(II) coordination compound were studied are depicted in Figure $7 . \mathrm{H}_{4} \mathrm{~L}$ displays strong emission peak at ca. $412 \mathrm{~nm}$ upon excitation at $271 \mathrm{~nm}$, and it should be attributed to the intra-ligand $\pi-\pi^{*}$ transition. The Co(II) coordination compound displays lower photoluminescence with maximum emission at ca. $360 \mathrm{~nm}$. Compared with $\mathrm{H}_{4} \mathrm{~L}$, emission intensity of the $\mathrm{Co}$ (II) coordination compound evidently reduces, showing that the $\mathrm{Co}(\mathrm{II})$ ions possess a certain degree of fluorescence quenching, which makes the conjugated system larger, and also indicates it may be a purple device. The solid-state fluorescence spectra of the ligand $\mathrm{H}_{4} \mathrm{~L}$ and its $\mathrm{Co}(\mathrm{II})$ coordination compound are depicted in Figure 8. Compared to liquid fluorescence spectroscopy, the ligand $\mathrm{H}_{4} \mathrm{~L}$ and its corresponding $\mathrm{Co}$ (II) coordination compound have strong fluorescence in solid-state fluorescence spectroscopy.

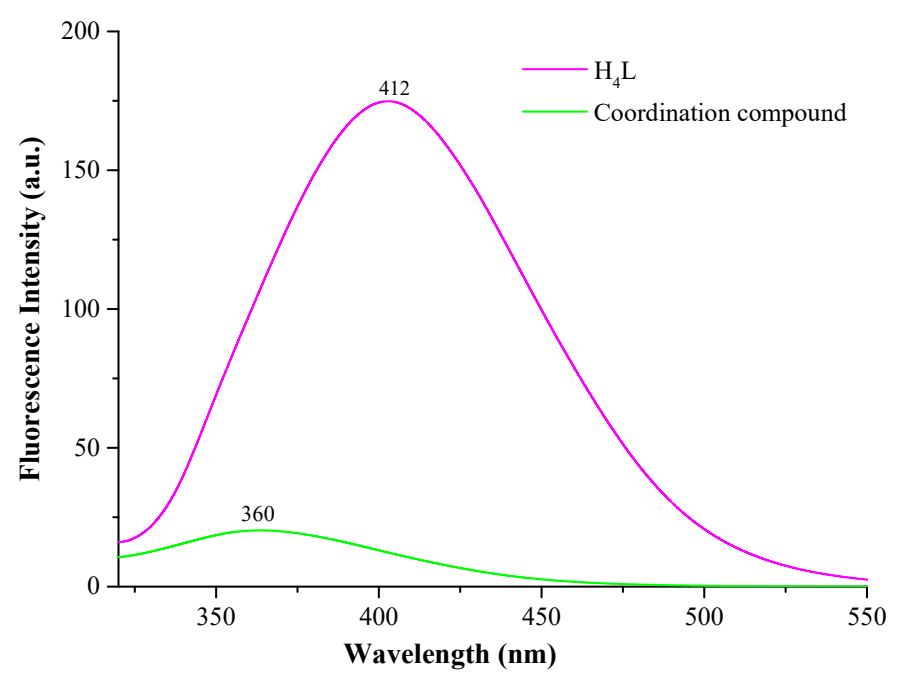

Figure 7. Fluorescence spectra of $\mathrm{H}_{4} \mathrm{~L}$ and its $\mathrm{Co}(\mathrm{II})$ coordination compound in dilute $\mathrm{CH}_{2} \mathrm{Cl}_{2}$ solutions $\left(\mathrm{c}=1 \times 10^{-6} \mathrm{M}, \lambda_{\mathrm{ex}}=271 \mathrm{~nm}\right)$. 


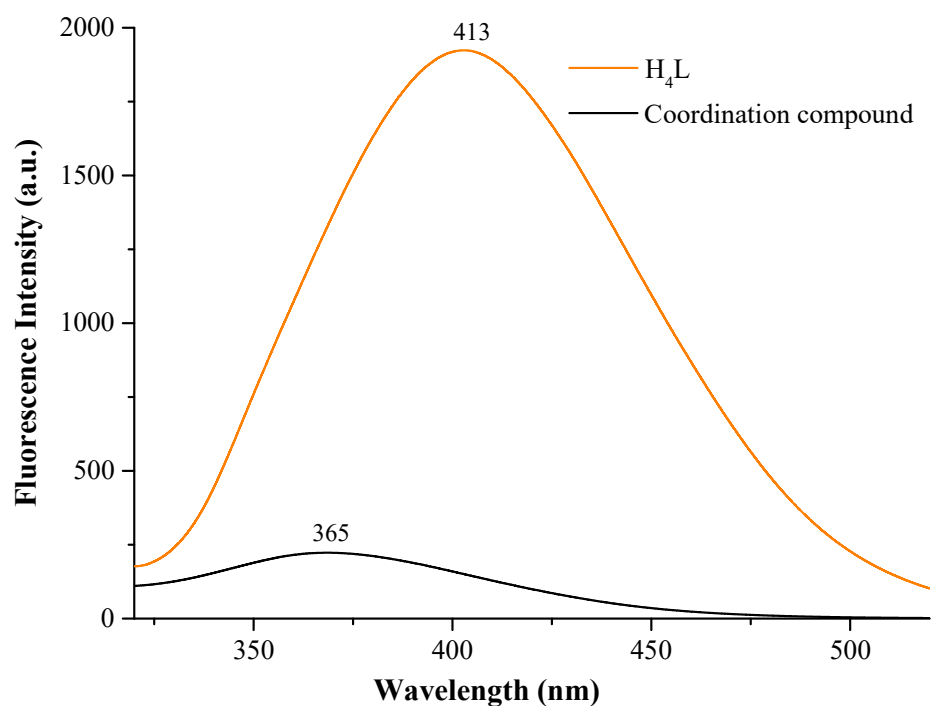

Figure 8. Fluorescence spectra of the ligand $\mathrm{H}_{4} \mathrm{~L}$ and its $\mathrm{Co}(\mathrm{II})$ coordination compound in the solid state.

\section{Conclusions}

In summary, we have synthesized and characterized a nonsymmetrical Salamo-type $\mathrm{N}_{2} \mathrm{O}_{2}$ ligand, and obtained an unprecedented hexanuclear $\mathrm{Co}$ (II) coordination compound, $\left[\left\{\mathrm{Co}_{3}(\mathrm{HL})(\mathrm{MeO})(\mathrm{MeOH})_{2}(\mathrm{OAc})_{2}\right\}_{2}\right] \cdot 2 \mathrm{MeOH}$. X-ray crystal structure analysis of the $\mathrm{Co}(\mathrm{II})$ coordination compound revealed that each $\mathrm{Co}$ (II) is hexacoordinated, and possesses distorted $\mathrm{CoO}_{6}$ or $\mathrm{CoO}_{4} \mathrm{~N}_{2}$ octahedrons. The $\mathrm{Co}(\mathrm{II})$ coordination compound possesses a $2 \mathrm{D}$ layered structure through intermolecular $\mathrm{C}-\mathrm{H} \cdots \mathrm{O}$ interactions. In addition, the fluorescence properties indicate that coordinated $\mathrm{Co}(\mathrm{II})$ ions resulted to the fluorescence quenching of $\mathrm{H}_{4} \mathrm{~L}$.

Acknowledgments: This work was supported by the National Natural Science Foundation of China (21761018) and the Program for Excellent Team of Scientific Research in Lanzhou Jiaotong University (201706), which is gratefully acknowledged.

Author Contributions: Wen-Kui Dong and Fei Wang conceived and designed the experiments; Bo-Xian Jin performed the experiments; Ling-Zhi Liu analyzed the data; Wen-Kui Dong contributed reagents/materials/analysis tools; Zong-Li Ren wrote the paper.

Conflicts of Interest: The authors declare no competing financial interests.

\section{References}

1. Zhou, J.J.; Song, X.Q.; Liu, Y.A.; Wang, X.L. Substituent-tuned structure and luminescence sensitizing towards $\mathrm{Al}^{3+}$ based on phenoxy bridged dinuclear Eu ${ }^{\mathrm{III}}$ complexes. RSC Adv. 2017, 7, 25549-25559. [CrossRef]

2. Xu, L.; Zhu, L.C.; Ma, J.C.; Zhang, Y.; Zhang, J.; Dong, W.K. Syntheses, structures and spectral properties of mononuclear $\mathrm{Cu}^{\mathrm{II}}$ and dimeric $\mathrm{Zn}^{\mathrm{II}}$ complexes based on an asymmetric Salamo-type $\mathrm{N}_{2} \mathrm{O}_{2}$ ligand. Z. Anorg. Allg. Chem. 2015, 641, 2520-2524. [CrossRef]

3. Dong, X.Y.; Li, X.Y.; Liu, L.Z.; Zhang, H.; Ding, Y.J.; Dong, W.K. Tri- and hexanuclear heterometallic $\mathrm{Ni}(\mathrm{II})-\mathrm{M}(\mathrm{II})(\mathrm{M}=\mathrm{Ca}$, Sr and Ba) bis(Salamo)-type complexes: Synthesis, structure and fluorescence properties. RSC Adv. 2017, 7, 48394-48403. [CrossRef]

4. Yang, Y.H.; Hao, J.; Dong, Y.J.; Wang, G. Two znic(II) complexes constructed from a bis(Salamo)-type tetraoxime ligand: Syntheses, crystal structures and luminescence properties. Chin. J. Inorg. Chem. 2017, 33, 1280-1292.

5. Chai, L.Q.; Huang, J.J.; Zhang, H.S. An unexpected cobalt (III) complex containing a schiff base ligand: Synthesis, crystal structure, spectroscopic behavior, electrochemical property and SOD-like activity. Spectrochim. Acta Part A 2014, 131, 526-530. [CrossRef] [PubMed] 
6. Chai, L.Q.; Tang, L.J.; Chen, L.C.; Huang, J.J. Structural, spectral, electrochemical and DFT studies of two mononuclear manganese(II) and zinc(II) complexes. Polyhedron 2017, 122, 228-240. [CrossRef]

7. Chai, L.Q.; Huang, J.J.; Zhang, J.Y.; Li, Y.X. Two 1-D and 2-D cobalt(II) complexes: Synthesis, crystal structures, spectroscopic and electrochemical properties. J. Coord. Chem. 2015, 68, 1224-1237. [CrossRef]

8. Chai, L.Q.; Zhang, K.Y.; Tang, L.J.; Zhang, J.Y.; Zhang, H.S. Two mono- and dinuclear Ni(II) complexes constructed from quinazoline-type ligands: Synthesis, $x$-ray structures, spectroscopic, electrochemical, thermal, and antimicrobial studies. Polyhedron 2017, 130, 100-107. [CrossRef]

9. Dong, Y.J.; Dong, X.Y.; Dong, W.K.; Zhang, Y.; Zhang, L.S. Three asymmetric Salamo-type copper(II) and cobalt(II) complexes: Syntheses, structures, fluorescent properties. Polyhedron 2017, 123, 305-315. [CrossRef]

10. Dong, W.K.; Ma, J.C.; Dong, Y.J.; Zhao, L.; Zhu, L.C.; Sun, Y.X.; Zhang, Y. Two hetero-trinuclear Zn(II)-M(II) $(\mathrm{M}=\mathrm{Sr}, \mathrm{Ba})$ complexes based on metallohost of mononuclear $\mathrm{Zn}(\mathrm{II})$ complex: Syntheses, structures and fluorescence properties. J. Coord. Chem. 2016, 69, 3231-3240. [CrossRef]

11. Dong, Y.J.; Ma, J.C.; Zhu, L.C.; Dong, W.K.; Zhang, Y. Four 3d-4f heteromultinuclear zinc(II)-lanthanide(III) complexes constructed from a distinct hexadentate $\mathrm{N}_{2} \mathrm{O}_{2}$-type ligand: Syntheses, structures and photophysical properties. J. Coord. Chem. 2017, 70, 103-115. [CrossRef]

12. Dong, W.K.; Akogun, S.F.; Zhang, Y.; Dong, X.Y. A reversible "turn-on" fluorescent sensor for selective detection of $\mathrm{Zn}^{2+}$. Sens. Actuators B 2017, 238, 723-734. [CrossRef]

13. Dong, W.K.; Ma, J.C.; Zhu, L.C.; Zhang, Y.; Li, X.L. Four new nickel(II) complexes based on an asymmetric Salamo-type ligand: Synthesis, structure, solvent effect and electrochemical property. Inorg. Chim. Acta 2016, 445, 140-148. [CrossRef]

14. Dong, W.K.; Zhu, L.C.; Dong, Y.J.; Ma, J.C.; Zhang, Y. Mono, di and heptanuclear metal(II) complexes based on symmetric and asymmetric tetradentate Salamo-type ligands: Syntheses, structures and spectroscopic properties. Polyhedron 2016, 117, 148-154. [CrossRef]

15. Ma, J.C.; Dong, X.Y.; Dong, W.K.; Zhang, Y.; Zhu, L.C.; Zhang, J.T. A new application of Salamo-type bisoximes: As a relay-sensor for $\mathrm{Zn}^{2+} / \mathrm{Cu}^{2+}$ and its novel complexes for successive sensing of $\mathrm{H}^{+} / \mathrm{OH}^{-}$. J. Coord. Chem. 2016, 69, 149-159. [CrossRef]

16. Chai, L.Q.; Liu, G.; Zhang, Y.L.; Huang, J.J.; Tong, J.F. Synthesis, crystal structure, fluorescence, electrochemical property, and SOD-like activity of an unexpected nickel(II) complex with a quinazoline-type ligand. J. Coord. Chem. 2013, 66, 3926-3938. [CrossRef]

17. Chai, L.Q.; Wang, G.; Sun, Y.X.; Dong, W.K.; Zhao, L.; Gao, X.H. Synthesis, crystal structure, and fluorescence of an unexpected dialkoxo-bridged dinuclear copper(II) complex with bis(Salen)-type tetraoxime. J. Coord. Chem. 2012, 65, 1621-1631. [CrossRef]

18. Chai, L.Q.; Zhang, H.S.; Dong, W.K.; Zhao, Y.L. Synthesis of unsymmetrical ureas with coumarin and thiadiazole ring under microwave irradiation. Phosphorus Sulfur Silicon 2010, 185, 1332-1337. [CrossRef]

19. Bella, S.D.; Fragalà, I. Chem Inform abstract: Synthesis and second-order nonlinear optical properties of bis(salicylaldiminato) M(II) metalloorganic materials. Synth. Met. 2000, 115, 191-196. [CrossRef]

20. Li, L.H.; Dong, W.K.; Zhang, Y.; Akogun, S.F.; Xu, L. Syntheses, structures and catecholase activities of homo- and hetero-trinuclear cobalt(II) complexes constructed from an acyclic naphthalenediol-based bis(Salamo)-type ligand. Appl. Organomet. Chem. 2017, 31, e3818. [CrossRef]

21. Li, X.Y.; Chen, L.; Gao, L.; Zhang, Y.; Akogun, S.F.; Dong, W.K. Syntheses, crystal structures and catalytic activities of two solvent-induced homotrinuclear $\mathrm{Co}(\mathrm{II})$ complexes with a naphthalenediol-based bis(Salamo)-type tetraoxime ligand. RSC Adv. 2017, 7, 35905-35916. [CrossRef]

22. Wu, H.L.; Pan, G.L.; Bai, Y.C.; Wang, H.; Kong, J. Synthesis, structure, antioxidation, and DNA-bindingstudies of a binuclear ytterbium(III) complex with bis(N-salicylidene)-3-oxapentane-1,5-diamine. Res. Chem. Intermed. 2015, 41, 3375-3388. [CrossRef]

23. Wu, H.L.; Bai, Y.C.; Zhang, Y.H.; Pan, G.L.; Kong, J.; Shi, F.; Wang, X.L. Two lanthanide(III) complexes based on the schiff base $N, N$-Bis(salicylidene)-1,5-diamino-3-oxapentane: Synthesis, characterization, DNA-binding properties, and antioxidation. Z. Anorg. Allg. Chem. 2014, 640, 2062-2071. [CrossRef]

24. Chen, C.Y.; Zhang, J.W.; Zhang, Y.H.; Yang, Z.H.; Wu, H.L. Gadolinium(III) and dysprosium(III) complexes with a schiff base bis( $\mathrm{N}$-salicylidene)-3-oxapentane-1,5-diamine: Synthesis, characterization, antioxidation, and DNA-binding studies. J. Coord. Chem. 2015, 68, 1054-1071. [CrossRef] 
25. Wu, H.L.; Bai, Y.C.; Zhang, Y.H.; Li, Z.; Wu, M.C.; Chen, C.Y.; Zhang, J.W. Synthesis, crystal structure, antioxidation and DNA-binding properties of a dinuclear copper(II) complex with bis( $N$-salicylidene)-3-oxapentane-1,5-diamine. J. Coord. Chem. 2014, 67, 3054-3066. [CrossRef]

26. Wu, H.L.; Pan, G.L.; Bai, Y.C.; Zhang, Y.H.; Wang, H.; Shi, F.R.; Wang, X.L.; Kong, J. Study on synthesis, crystal structure, antioxidant and DNA-binding of mono-, di-and poly-nuclear lanthanides complexes with bis (N-salicylidene)-3-oxapentane-1, 5-diamine. J. Photochem. Photobiol. B 2014, 135, 33-43. [CrossRef] [PubMed]

27. Wu, H.L.; Pan, G.L.; Bai, Y.C.; Wang, H.; Kong, J.; Shi, F.R.; Zhang, Y.H.; Wang, X.L. Preparation, structure, DNA-binding properties, and antioxidant activities of a homodinuclear erbium(III) complex with a pentadentate schiff base ligand. J. Chem. Res. 2014, 38, 211-217. [CrossRef]

28. Wu, H.L.; Wang, C.P.; Wang, F.; Peng, H.P.; Zhang, H.; Bai, Y.C. A new manganese(III) complex from bis(5-methylsalicylaldehyde)-3-oxapentane-1,5-diamine: Synthesis, characterization, antioxidant activity and luminescence. J. Chin. Chem. Soc. 2015, 62, 1028-1034. [CrossRef]

29. Wu, H.L.; Bai, Y.; Yuan, J.K.; Wang, H.; Pan, G.L.; Fan, X.Y.; Kong, J. A zinc(II) complex with tris(2-(N-methyl)benzimidazlylmethyl)amine and salicylate: Synthesis, crystal structure, and DNA-binding. J. Coord. Chem. 2012, 65, 2839-2851. [CrossRef]

30. Song, X.Q.; Liu, P.P.; Wang, C.Y.; Liu, Y.A.; Liu, W.S.; Zhang, M. Three sandwich-type zinc(II)-lanthanide(III) clusters: Structures, luminescence and magnetic properties. RSC Adv. 2017, 7, 22692-22698. [CrossRef]

31. Zheng, S.S.; Dong, W.K.; Zhang, Y.; Chen, L.; Ding, Y.J. Four Salamo-type 3d-4f hetero-bimetallic $\left[\mathrm{Zn}^{\mathrm{II}} \mathrm{Ln}^{\mathrm{III}}\right]$ complexes: Syntheses, crystal structures, and luminescent and magnetic properties. New J. Chem. 2017, 41, 4966-4973. [CrossRef]

32. Dong, W.K.; Ma, J.C.; Zhu, L.C.; Zhang, Y. Nine self-assembled nickel(II)-lanthanide(III) heterometallic complexes constructed from a Salamo-type bisoxime and bearing $N$ - or $O$-donor auxiliary ligand: Syntheses, structures and magnetic properties. New J. Chem. 2016, 40, 6998-7010. [CrossRef]

33. Sun, Y.X.; Wang, L.; Dong, X.Y.; Ren, Z.L.; Meng, W.S. Synthesis, characterization, and crystal structure of a supramolecular $\mathrm{CO}^{\mathrm{II}}$ complex containing Salen-type bisoxime. Synth. React. Inorg. Met.-Org. Nano Met. Chem. 2013, 43, 599-603. [CrossRef]

34. Sun, Y.X.; Xu, L.; Zhao, T.H.; Liu, S.H.; Dong, X.T. Synthesis and crystal structure of a 3D supramolecular copper(II) complex with 1-(3-\{[(E)-3-bromo-5-chloro-2-hydroxybenzylidene]amino\}phenyl) ethanoneoxime. Synth. React. Inorg. Met.-Org. Nano Met. Chem. 2013, 43, 509-513. [CrossRef]

35. Sun, Y.X.; Zhang, S.T.; Ren, Z.L.; Dong, X.Y.; Wang, L. Synthesis, characterization, and crystal structure of a new supramolecular $\mathrm{Cd}^{\mathrm{II}}$ complex with halogen-substituted Salen-type bisoxime. Synth. React. Inorg. Met.-Org. Nano Met. Chem. 2013, 43, 995-1000. [CrossRef]

36. Sun, Y.X.; Gao, X.H. Synthesis, characterization, and crystal structure of a new CuII complex with Salen-type ligand. Synth. React. Inorg. Met.-Org. Nano Met. Chem. 2011, 41, 973-978. [CrossRef]

37. Song, X.Q.; Liu, P.P.; Xiao, Z.R.; Li, X.; Liu, Y.A. Four polynuclear complexes based on a versatile salicylamide Salen-like ligand: Synthesis, structural variations and magnetic properties. Inorg. Chim. Acta 2015, 438, 232-244. [CrossRef]

38. Liu, Y.A.; Wang, C.Y.; Zhang, M.; Song, X.Q. Structures and magnetic properties of cyclic heterometallic tetranuclear clusters. Polyhedron 2017, 127, 278-286. [CrossRef]

39. Liu, P.P.; Wang, C.Y.; Zhang, M.; Song, X.Q. Pentanuclear sandwich-type Zn ${ }^{\mathrm{II}}$-Ln ${ }^{\mathrm{III}}$ clusters based on a new Salen-like salicylamide ligand: Structure, near-infrared emission and magnetic properties. Polyhedron 2017, 129, 133-140. [CrossRef]

40. Liu, P.P.; Sheng, L.; Song, X.Q.; Xu, W.Y.; Liu, Y.A. Synthesis, structure and magnetic properties of a new one dimensional manganese coordination polymer constructed by a new asymmetrical ligand. Inorg. Chim. Acta 2015, 434, 252-257. [CrossRef]

41. Song, X.Q.; Peng, Y.J.; Chen, G.Q.; Wang, X.R.; Liu, P.P.; Xu, W.Y. Substituted group-directed assembly of $\mathrm{Zn}(\mathrm{II})$ coordination complexes based on two new structural related pyrazolone based Salen ligands: Syntheses, structures and fluorescence properties. Inorg. Chim. Acta 2015, 427, 13-21. [CrossRef]

42. Song, X.Q.; Liu, P.P.; Liu, Y.A.; Zhou, J.J.; Wang, X.L. Two dodecanuclearheterometallic $\left[Z_{6} \operatorname{Ln}_{6}\right]$ clusters constructed by a multidentate salicylamide Salen-like ligand: Synthesis, structure, luminescence and magnetic properties. Dalton. Trans. 2016, 45, 8154-8163. [CrossRef] [PubMed] 
43. Wang, L.; Hao, J.; Zhai, L.X.; Zhang, Y.; Dong, W.K. Synthesis, crystal structure, luminescence, electrochemical and antimicrobial properties of bis(Salamo)-based Co(II) complex. Crystals 2017, 7, 277. [CrossRef]

44. Akine, S. Novel ion recognition systems based on cyclic and acyclic oligo(Salen)-type ligands. J. Incl. Phenom. Macrocycl. Chem. 2012, 72, 25-54. [CrossRef]

45. Zhang, H.; Dong, W.K.; Zhang, Y.; Akogun, S.F. Naphthalenediol-based bis(Salamo)-type homo- and heterotrinuclear cobalt(II) complexes: Syntheses, structures and magnetic properties. Polyhedron 2017, 133, 279-293. [CrossRef]

46. Li, X.Y.; Kang, Q.P.; Liu, L.Z.; Ma, J.C.; Dong, W.K. Trinuclear Co(II) and mononuclear Ni(II) Salamo-type bisoxime coordination compounds. Crystals 2018, 8, 43. [CrossRef]

47. Dong, W.K.; Li, G.; Wang, Z.K.; Dong, X.Y. A novel trinuclear cobalt(II) complex derived from an asymmetric Salamo-type $\mathrm{N}_{2} \mathrm{O}_{3}$ bisoxime chelate ligand: Synthesis, structure and optical properties. Spectrochim. Acta Part A 2014, 133, 340-347. [CrossRef] [PubMed]

48. Dong, X.Y.; Akogun, S.F.; Zhou, W.M.; Dong, W.K. Tetranuclear Zn(II) complex based on an asymmetrical Salamo-type chelating ligand: Synthesis, structural characterization, and fluorescence property. J. Chin. Chem. Soc. 2017, 64, 412-419. [CrossRef]

49. Dong, W.K.; Ma, J.C.; Zhu, L.C.; Zhang, Y. Self-assembled zinc(II)-lanthanide(III) heteromultinuclear complexes constructed from 3-MeO Salamo ligand: Syntheses, structures and luminescent properties. Cryst. Growth Des. 2016, 16, 6903-6914. [CrossRef]

50. Zhao, L.; Dang, X.T.; Chen, Q.; Zhao, J.X.; Wang, L. Synthesis, crystal structure and spectral properties of a 2D supramolecular copper(II) complex with 1-(4-\{[(E)-3-ethoxyl-2-hydroxybenzy lidene]amino\}phenyl)ethanoneoxime. Synth. React. Inorg. Met.-Org. Nano Met. Chem. 2013, 43, 1241-1246. [CrossRef]

51. Zhao, L.; Wang, L.; Sun, Y.X.; Dong, W.K.; Tang, X.L.; Gao, X.H. A supramolecular copper(II) complex bearing Salen-type bisoxime ligand: Synthesis, structural characterization, and thermal property. Synth. React. Inorg. Met.-Org. Nano Met. Chem. 2012, 42, 1303-1308. [CrossRef]

52. Wang, P.; Zhao, L. An infinite 2D supramolecular cobalt(II) complex based on an asymmetric Salamo-type ligand: Synthesis, crystal structure, and spectral properties. Synth. React. Inorg. Met.-Org. Nano Met. Chem. 2016, 46, 1095-1101. [CrossRef]

53. Wang, P.; Zhao, L. Synthesis, structure and spectroscopic properties of the trinuclear cobalt(II) and nickel(II) complexes based on 2-hydroxynaphthaldehyde and bis(aminooxy)alkane. Spectrochim. Acta Part A 2015, 135, 342-350. [CrossRef] [PubMed]

54. Wang, L.; Ma, J.C.; Dong, W.K.; Zhu, L.C.; Zhang, Y. A novel self-assembled nickel(II)-cerium(III) heterotetranuclear dimer constructed from $\mathrm{N}_{2} \mathrm{O}_{2}$-type bisoxime and terephthalic acid: Synthesis, structure and photophysical properties. Z. Anorg. Allg. Chem. 2016, 642, 834-839. [CrossRef]

55. Dong, W.K.; Li, X.L.; Wang, L.; Zhang, Y.; Ding, Y.J. A new application of Salamo-type bisoximes: As a relay-sensor for $\mathrm{Zn}^{2+} / \mathrm{Cu}^{2+}$ and its novel complexes for successive sensing of $\mathrm{H}^{+} / \mathrm{OH}^{-}$. Sens. Actuators $B$ 2016, 229, 370-378. [CrossRef]

56. Dong, W.K.; Zhang, J.T.; Dong, Y.J.; Zhang, Y.; Wang, Z.K. Construction of mononuclear copper(II) and trinuclear cobalt(II) complexes based on asymmetric Salamo-type ligands. Z. Anorg. Allg. Chem. 2016, 642, 189-196. [CrossRef]

57. Dong, W.K.; Sun, Y.X.; He, X.N.; Tong, J.F.; Wu, J.C. Trinuclear and mononuclear copper(II) complexes incorporating tetradentate $2,2^{\prime}-\left[1,1^{\prime}\right.$-(ethylenedioxydinitrilo)diethylidyne]diphenol ligand: Syntheses, crystal structures, spectral and thermal behaviors. Spectrochim. Acta Part A 2010, 76, 476-483. [CrossRef] [PubMed]

58. Dong, W.K.; Li, X.; Yang, C.J.; Zhao, M.M.; Li, G.; Dong, X.Y. Syntheses and crystal structures of 5-methoxy-6'-hydroxy-2,2' -[ethylenedioxybis(nitrilomethylidyne)]diphenol and its tetranuclear zinc(II) complex. Chin. J. Inorg. Chem. 2014, 30, 710-716.

59. Dong, W.K.; Zhang, F.; Li, N.; Xu, L.; Zhang, Y.; Zhang, J.; Zhu, L.C. Trinuclear cobalt(II) and zinc(II) Salamo-type complexes: Syntheses, crystal structures, and fluorescent properties. Z. Anorg. Allg. Chem. 2016, 642, 532-538. [CrossRef]

60. Chen, L.; Dong, W.K.; Zhang, H.; Zhang, Y.; Sun, Y.X. Structural variation and luminescence properties of trianddinuclear $\mathrm{Cu}^{\mathrm{II}}$ and $\mathrm{Zn}^{\mathrm{II}}$ complexes constructed from a naphthalenediol-based bis(Salamo)-type ligand. Cryst. Growth Des. 2017, 17, 3636-3648. [CrossRef] 
61. Wang, F.; Gao, L.; Zhao, Q.; Zhang, Y.; Dong, W.K.; Ding, Y.J. A highly selective fluorescent chemosensor for $\mathrm{CN}^{-}$based on a novel bis(Salamo)-type tetraoxime ligand. Spectrochim. Acta Part A 2018, 190, 111-115. [CrossRef] [PubMed]

62. Dong, X.Y.; Gao, L.; Wang, F.; Zhang, Y.; Dong, W.K. Tri- and mono-nuclear zinc(II) complexes based onhalfand mono-Salamo chelating ligands. Crystals 2017, 7, 267. [CrossRef]

63. Peng, Y.D.; Li, X.Y.; Kang, Q.P.; An, G.X.; Zhang, Y.; Dong, W.K. Synthesis and fluorescence properties of asymmetrical Salamo-type tetranuclear zinc(II) complex. Crystals 2018, 8, 107. [CrossRef]

64. Hao, J.; Liu, L.Z.; Dong, W.K.; Zhang, J.; Zhang, Y. Three multinuclear Co(II), Zn(II) and Cd(II) complexes based on a single-armed Salamo-type bisoxime: Syntheses, structural characterizations and fluorescent properties. J. Coord. Chem. 2017, 70, 1936-1952. [CrossRef]

65. Wang, L.; Li, X.Y.; Zhao, Q.; Li, L.H.; Dong, W.K. Fluorescence properties of heterotrinuclear Zn(II)-M(II) $(\mathrm{M}=\mathrm{Ca}$, Sr and Ba) bis(Salamo)-type complexes. RSC Adv. 2017, 7, 48730-48737. [CrossRef]

66. Akine, S.; Morita, Y.; Utsuno, F.; Nabeshima, T. Multiple folding structures mediated by metal coordination of acyclic multidentate ligand. Inorg. Chem. 2009, 48, 10670-10678. [CrossRef] [PubMed]

67. Gao, L.; Liu, C.; Wang, F.; Dong, W.K. Tetra-, penta- and hexa-coordinated transition metal complexes constructed from coumarin-containing $\mathrm{N}_{2} \mathrm{O}_{2}$ ligand. Crystals 2018, 8, 77. [CrossRef]

68. Li, G.; Hao, J.; Liu, L.Z.; Zhou, W.M.; Dong, W.K. Syntheses, crystal structures and thermal behaviors of two supramolecular Salamo-type cobalt(II) and zinc(II) complexes. Crystals 2017, 7, 217.

69. Gao, L.; Wang, F.; Zhao, Q.; Zhang, Y.; Dong, W.K. Mononuclear Zn(II) and trinuclear Ni(II) complexes derived from a coumarin-containing $\mathrm{N}_{2} \mathrm{O}_{2}$ ligand: Syntheses, crystal structures and fluorescence properties. Polyhedron 2018, 139, 7-16. [CrossRef]

70. Hao, J.; Li, L.H.; Zhang, J.T.; Akogun, S.F.; Wang, L.; Dong, W.K. Four homo- and hetero-bismetallic 3d/3d-2s complexes constructed from a naphthalenediol-based acyclic bis(Salamo)-type tetraoxime ligand. Polyhedron 2017, 134, 1-10. [CrossRef]

71. Dong, X.Y.; Sun, Y.X.; Wang, L.; Li, L. Synthesis and structure of a penta- and hexa-coordinated tri-nuclear cobalt(II) complex. J. Chem. Res. 2012, 36, 387-390. [CrossRef]

72. Dong, W.K.; Zhang, J.; Zhang, Y.; Li, N. Novel multinuclear transition metal(II) complexes based on an asymmetric Salamo-type ligand: Syntheses, structure characterizations and fluorescent properties. Inorg. Chim. Acta 2016, 444, 95-102. [CrossRef]

73. Dong, X.Y.; Kang, Q.P.; Li, X.Y.; Ma, J.C.; Dong, W.K. Structurally characterized solvent-induced homotrinuclear cobalt(II) $\mathrm{N}_{2} \mathrm{O}_{2}$-donor bisoxime-type complexes. Crystals 2018, 8, 139. [CrossRef]

74. Dong, W.K.; Sun, Y.X.; Zhao, C.Y.; Dong, X.Y.; Xu, L. Synthesis, structure and properties of supramolecular $\mathrm{Mn}^{\mathrm{II}}, \mathrm{Co}^{\mathrm{II}}, \mathrm{Ni}^{\mathrm{II}}$ and $\mathrm{Zn}^{\mathrm{II}}$ complexes containing Salen-type bisoxime ligands. Polyhedron 2010, 29, 2087-2097. [CrossRef]

75. Wang, B.J.; Dong, W.K.; Zhang, Y.; Akogun, S.F. A novel relay-sensor for highly sensitive and selective detection of $\mathrm{Zn}^{2+} / \mathrm{Pic}^{-}$and fluorescence on/off switch response of $\mathrm{H}^{+} / \mathrm{OH}^{-}$. Sens. Actuators B 2017, 247, 254-264. [CrossRef]

76. Dong, W.K.; Du, W.; Zhang, X.Y.; Li, G.; Dong, X.Y. Synthesis, crystal structure and spectral properties of a supramolecular trinuclear nickel(II) complex with 5-methoxy-4'-bromo-2,2'-[ethylenedioxybis(nitrilomethylidyne)]diphenol. Spectrochim. Acta Part A 2014, 132, 588-593. [CrossRef] [PubMed]

77. Dong, Y.J.; Li, X.L.; Zhang, Y.; Dong, W.K. A highly selective visual and fluorescent sensor for $\mathrm{Pb}^{2+}$ and $\mathrm{Zn}^{2+}$ and crystal structure of $\mathrm{Cu}^{2+}$ complex based-on a novel single-armed Salamo-type bisoxime. Supramol. Chem. 2017, 29, 518-527. [CrossRef]

78. Akine, S.; Dong, W.K.; Nabeshima, T. Octanuclearzinc(II) and cobalt(II) clusters produced by cooperative tetrameric assembling of oxime chelate ligands. Inorg. Chem. 2006, 45, 4677-4684. [CrossRef] [PubMed]

79. Kruszynski, R.; Siera'nski, T. Can stacking interactions exist beyond the commonly accepted limits? Cryst. Growth Des. 2016, 16, 587-595. [CrossRef]

80. Bernstein, J.; Davis, R.E.; Shimoni, L.; Chang, N.L. Patterns in hydrogen bonding: Functionality and graph set analysis in crystals. Angew. Chem. Int. Ed. Engl. 1995, 34, 1555-1573. [CrossRef]

81. Percy, G.; Thornton, D. Infrared spectra of $N$-aryl salicylaldimine complexes substituted in both aryl rings. J. Inorg. Nucl. Chem. 1973, 35, 2319-2327. [CrossRef] 
82. Song, X.Q.; Wang, L.; Zheng, Q.F.; Liu, W.S. Synthesis, crystal structure and luminescence properties of lanthanide complexes with a new semirigid bridging furfurylsalicylamide ligand. Inorg. Chim. Acta 2013, 391, 171-178. [CrossRef]

83. Song, X.Q.; Cheng, G.Q.; Wang, X.R.; Xu, W.Y.; Liu, P.P. Structure-based description of a step-by-step synthesis of heterodinuclear $\mathrm{Zn}^{\mathrm{II}} \mathrm{Ln}^{\mathrm{III}}$ complexes and their luminescence properties. Inorg. Chim. Acta 2015, 425, 145-153. [CrossRef]

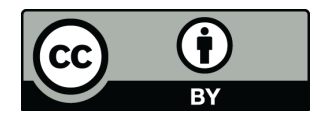

(C) 2018 by the authors. Licensee MDPI, Basel, Switzerland. This article is an open access article distributed under the terms and conditions of the Creative Commons Attribution (CC BY) license (http://creativecommons.org/licenses/by/4.0/). 